\title{
PERBEDAAN HASIL BELAJAR FISIKA PESERTA DIDIK KELAS XI DENGAN MODEL KOOPERATIF BERBANTUAN ADVANCE ORGANIZER DAN PEMBELAJARAN BERBASIS MASALAH
}

\section{DIFFERENCES STUDENTS PHYSICS LEARNING OUTCOMES GRADE XI WITH COOPERATIVE MODEL ASSISTED ADVANCE ORGANIZER AND PROBLEM BASED LEARNING}

\author{
Miskul Ruliyanti, Ahmad Harjono, Satutik Rahayu \\ Program Studi Pendidikan Fisika FKIP Universitas Mataram, Mataram, Indonesia \\ E-mail : miskultheblog@gmail.com
}

Diterima : 9 Juli 2019. Disetujui : 26 Juli 2019. Dipublikasikan : 9 Januari 2020

\begin{abstract}
Abstrak : Penelitian ini bertujuan untuk mengetahui perbedaan hasil belajar fisika peserta didik kelas XI dengan model kooperatif berbantuan advance organizer dan pembelajaran berbasis masalah. Jenis penelitian ini adalah quasi-experiment dengan desain Pretest-Posttest Control Group Design. Populasi yang digunakan adalah seluruh peserta didik kelas XI SMA Negeri 3 Mataram dengan teknik pengambilan sampel cluster sampling, sehingga sampel yang terpilih adalah kelas XI MIA 6 sebagai kelas eksperimen 1 dan XI MIA 3 sebagai kelas eksperimen 2. Sebelum diberi perlakuan, kedua kelas diberikan tes untuk mengetahui kemampuan awal peserta didik. Berdasarkan hasil uji homogenitas tes awal kedua sampel memiliki kemampuan awal yang sama. Hasil tes akhir sebagai hasil belajar diperoleh nilai rata-rata kelas eksperimen 1 sebesar 63,63 dengan nilai tertinggi 76 dan nilai rata-rata kelas eksperimen 2 sebesar 47,76 dengan nilai tertinggi 72. Hipotesis penelitian diuji dengan uji Mann-Whiteney karena $\chi^{2}$ hitung $>\chi_{\text {tabel }}^{2}$ maka kedua sampel tidak terdistribusi normal, sehingga diperoleh nilai $Z_{\text {hitung }}>Z_{\text {tabel }}$ yaitu $4,98>1,96$. Disimpulkan bahwa terdapat perbedaan hasil belajar fisika peserta didik kelas XI dengan model kooperatif berbantuan advance organizer dan pembelajaran berbasis masalah.
\end{abstract}

Kata Kunci : Model kooperatif, advance organizer, pembelajaran berbasis masalah, hasil belajar

Abstract : Purpose of this research to know differences students physics learning outcomes grade XI with cooperative model assisted advance organizer and problem based learning. The research type is quasiexperiment with pretest-posttest control group design. The Population of this study is all students of class XI MIA in SMAN 3 Mataram, with sampling technique using Cluster Sampling. The classed the sampled are class XI MIA 6 as experiment class 1 and XI MIA 3 as experiment class 2. Before treatment, both of class gived test to detected students ability early. Be based on homogenenity test result of first test both sample have prior knowledge is same. Result of final test as learning outcomes to be obtain experiment class 1 average value equal 63,63 with highest value is 76 and experiment class 2 average value equal 47,76 with highest value 72 . Hypothesis of research tested with Mann-Whiteney test because $\chi_{\text {nitung }}{ }^{2} \chi_{\text {tabel }}{ }^{2}$. Hence both of sample unnormal distribution. So that obtained $Z_{\text {hitung }}>Z_{\text {tabel }}$ value is $4,98>1$ 1,96. Conclude is there are differences students physics learning outcomes grade XI with cooperative model assisted advance organizer and problem based learning.

Keywords : Cooperative model, advance organizer, problem based learning, learning outcomes

\section{PENDAHULUAN}

Fisika merupakan ilmu yang mempelajari segala gejala alam serta materi dalam lingkup ruang dan waktu. Fisika pada hakikatnya merupakan pembelajaran yang memerlukan kreativitas, pemikiran kritis dan sikap ilmiah dalam memahami konsep maupun memecahkan permasalahan. Belajar fisika yang baik sangat didukung dengan peserta didik yang aktif dalam proses kegiatan belajar mengajar. Belajar merupakan usaha sadar yang dilakukan untuk memperoleh informasi dan merubah pola tigkah laku untuk menjadi lebih baik dalam mengembangkan keterampilan berpikir. Peningkatan kemampuan peserta didik ditandai dengan hasil belajar yang dicapai dalam pembelajaran. Hasil belajar yang diperoleh oleh seseorang akan sangat bergantung pada masukan saat proses belajar, sehingga memungkinkan kemampuan dapat teramati [1]. Berdasarkan hasil observasi pada peserta didik kelas XI MIA di SMA Negeri 3 Mataram, beberapa permasalahan yang dihadapi saat proses pembelajaran adalah keaktifan peserta didik dalam belajar kurang, pengetahuan awal yang dimiliki sulit untuk diterapkan ketika mempelajari materi baru, kesulitan dalam memahami konsep fisika, kebosanan dalam belajar dikarenakan banyak persamaan matematis dan sebagainya. Permasalahan ini akan menyebabkan kurang optimalnya pengembangan potensi diri peserta didik. Hal ini akan semakin terhambat untuk berkembang jika tidak terjalin komunikasi dan interaksi yang baik antar peserta didik dalam memperoleh informasi. Kesenjangan antara pengetahuan yang sudah diterima dengan informasi baru yang akan disampaikan menimbulkan 
miskomunikasi dalam memahami pembelajaran. Hal tersebut menyebabkan peserta didik sulit dalam menerima materi yang baru. Mengatasi hal ini diperlukan suatu jembatan atau bantuan yang dapat menghubungkan pengetahuan peserta didik dalam menerima materi pembelajaran.

Terkait pada permasalahan tersebut, model pembelajaran yang menjadi solusi menurut peneliti adalah model kooperatif berbantuan advance organizer dan pembelajaran berbasis masalah. Model kooperatif merupakan bagian dari pembelajaran kontruktivis, yang menggunakan sistem pengelompokkan kecil yang rangkaian kegiatan belajarnya mulai dari di sampaikan tujuan pembelajaran oleh guru, pembimbingan belajar, sampai kepada pemberian penghargaan kepada anggota kelompok yang dianggap baik [2]. Keuntungan model kooperatif yaitu memudahkan peserta didik melakukan penyesuaian diri secara sosial; menghilangkan sifat mementingkan diri sendiri; meningkatkan kemampuan memandang masalah dan siatuasi dari berbagai perspektif; serta terbentuknya nilai-nilai sosial dan komitmen [3]. Hal penting yang diperoleh pada pembelajaran kooperatif adalah peserta didik belajar melalui interaksi dengan teman sebaya sehingga memberikan pemikiran yang terbuka untuk seluruh peserta didik, dalam mengungkapkan keinginan belajar [4].

Solusi permasalahan untuk mengaitkan pengetahuan awal peserta didik dengan informasi yang akan diterima digunakanlah advance organizer berupa peta konsep. Ausubel bahwa "advance organizers are technique for helping student access prior knowledge that in turn can clarify instructional material presented to them and an advance organizer is introductory material at a higher level of abstraction,generality, an inclusiveness than learning passage it self. Advance organizer is information that presented prior to learning and can be used by the learner to organize and interpret new incoming information" [5].

Advance organizer (AO) merupakan gambaran umum dari materi pengantar pada level yang tinggi, keadaan yang umum, dan termasuk bagian tersendiri. AO sebagai pemberian informasi awal belajar dan dapat digunakan oleh pebelajar untuk mengorganisasikan dan mengartikan informasi baru yang diterima. Lebih jelasnya Ausubel menyatakan bahwa "Advance organizer are design to facilitate the meaningful learning of unitary topic, or closely related sets of ideas" ([6]. AO memperkuat kognitif dan mempertinggi daya ingat tentang informasi baru serta rancangan untuk memfasilitasi pembelajaran yang bermakna dari topik yang satu atau relasi kedekatannya dengan ide. Advance organizer dipresentasikan dalam beberapa bentuk yaitu dalam bentuk konsep, menggunakan tujuan pembelajaran, dan memanfaatkan oral advance organizer [5]. Proses belajar peserta didik dalam menghubungkan antar konsep yang telah diketahuinya dapat mengaitkan pengetahuan awal dengan yang baru maka akan menjadi pembelajaran yang bermakna. Pembelajaran dengan AO dapat memberikan manfaat [7]. Sehubungan dengan hal itu, trategi AO dapat memberikan tiga manfaat, yaitu : (1) menyediakan suatu kerangka konseptual untuk materi belajar; (2) menjadi jembatan penghubung antara materi yang akan di pelahari dengan pengetahuan sebelumnya; (3) membantu peserta didik untuk memahami bahan belajar secara lebih mudah. Antara pembelajaran kooperatif dengan bantuan advance organizer berupa peta konsep, keduanya dapat memberikan dukungan dengan baik, kooperatif dalam meningkatkan prestasi belajar dan advance organizer sebagai penguhubung pengetahuan bagi peserta didik [8]. Pembelajaran kooperatif berbantuan AO menggunakan tahap pembelajaran kooperatif mulai dari penyampaian tujuan sampai kepada memberikan penghargaan kepada kelompok kooperatif dengan bantuan AO yang diberikan pada tahap awal pembelajaran. Hal ini dilakukan untuk membangun pengetahuan peserta didik dengan baik di awal. Pembelajaran kooperatif tidak hanya mempelajari materi saja, namun harus mempelajari keterampilan kooperatif yang berfungsi melancarkan hubungan kerja sama kelompok. Akibatnya, peserta didik dapat menyelesaikan permasalahan secara baik [9].

Memperoleh hasil belajar yang baik tidak hanya melalui kerjasama dalam kelompok belajar, akan tetapi diperlukan juga cara belajar yang khusus untuk menganalisis permasalahan yang berkaitan dengan fisika. Salah satunya adalah dengan menggunakan pembelajaran berbasis masalah (PBM). Pembelajaran berbasis masalah merupakan suatu rangkaian aktivitas pembelajaran yang menuntut peserta didik untuk menyelesaiakan pesoalan yang sedang dihadapi.

Peserta didik tidak hanya aktif dalam belajar akan tetapi dapat menyelesaiakan masalah dengan menggunakan pendekatan berpikir secara ilmiah. Permasalahan yang diberikan kepada peserta didik merupakan permasalahan yang bersifat terbuka yaitu tidak hanya bersumber dari sumber belajar tetapi juga dari lingkungan belajar peserta didik yang berkaitan dengan materi pembelajaran. Masalah yang diberikan merupakan kesenjangan antara situasi nyata dengan kondisi yang diharapkan [2]. Pembelajaran ini menuntut peserta didik untuk mampu memecahkan permasalahan mulai dari menganalisis masalah, merumuskan, maupun memberikan kesimpulan dari permasalahan yang diajukan. PBM memiliki manfaat yakni membantu peserta didik untuk mengembangkan kemampuan berpikir, dalam menghadapi masalah dan merasa tertantang untuk 
menyelesaikan masalah tersebut, memupuk solidaritas sosial dengan terbiasa diskusi dengan teman sekelas [10]. Hasil belajar dari pembelajaran berbasis masalah adalah peserta didik memiliki keterampilan penyelidikan, baik dalam mengatasi masalah, kemampuan mempelajari peran dengan baik, maupun jadi pembelajar yang mandiri dan independen, dalam pembelajaran ini peserta didik akan bertanggung jawab dalam menyelesaikan masalah yang diajukan secara ilmiah [11].

\section{METODE PENELITIAN}

Jenis penelitian yang digunakan adalah quasi-experiment dengan desain pretest-posttest control group design. Penelitian ini melibatkan variabel bebas,

yaitu model kooperatif berbantuan advance organizer dan pembelajaran berbasis masalah, serta variabel terikat adalah hasil belajar, dan variabel kontrolnya yaitu materi pembelajaran fluida statis, guru yang mengajar, instrumen tes dan cara penilaian kedua kelas eksperimen adalah sama. Penelitian ini dilakukan di SMAN 3 Mataram tahun ajaran 2018/2019. Populasi penelitian ini adalah seluruh kelas XI MIA dengan sampel dipilih secara cluster sampling. Sampel penelitian terdiri dari dua kelas eksperimen yaitu XI MIA 6 sebagai kelas eksperimen 1 dan XI MIA 3 sebagai kelas eksperimen 2. Instrumen yang digunakan adalah tes untuk hasil belajar pada ranah kognitif. Teknik pengumpulan data menggunakan tes pilihan ganda sebanyak 25 soal yang sudah memenuhi beberapa syarat yaitu uji validitas, uji reliabilitas, daya beda dan tingkat kesukaran. Uji analisis data menggunakan uji Mann-Whiteney (uji-U) dengan taraf siginfikan $5 \%$.

\section{HASIL DAN PEMBAHASAN}

Penelitian ini bertujuan untuk mengetahui perbedaan hasil belajar fisika peserta didik kelas XI dengan model kooperatif berbantuan advance organizer dan pembelajaran berbasis masalah. Kemampuan yang diukur pada peserta didik hanya pada ranah kognitif antara kedua sampel, yaitu kelas XI MIA 6 (eksperimen 1) dengan XI MIA 3 (eksperimen 2) yang diberikan tes awal sebelum diberikan perlakuan maupun tes akhir setelah perlakuan dengan soal pilihan ganda yang sama sebanyak 25 soal.

Data hasil tes kemampuan awal kedua kelas eksperimen dilakukan untuk mengetahui besarnya kemampuan awal peserta didik sebelum diberikan perlakuan dapat dilihat pada tabel 1 .

Tabel 1 menunjukan jumlah peserta didik kedua kelas eksperimen sama dengan nilai tertinggi yang diperoleh juga sama yaitu 40. Nilai terendah di kelas eksperimen 1 adalah 12 dengan rata-rata 25,21. Kelas eksperimen 2 memperoleh nilai terendah 8 dengan rata-rata 24,24 dengan selisih hanya 0,97 . Tes akhir hasil belajar fisika dapat ditunjukan pada Tabel 2 bahwa rata-rata hasil belajar 33 peserta didik pada kelas eksperimen 1 adalah 63,64 yang dikategorikan cukup, sedangkan kelas eksperimen 2 sebesar 47,76 dapat dikategorikan kurang. Tabel 2 juga menunjukan bahwa nilai maksimum yang mampu dicapai oleh peserta didik pada kelas eksperimen 1 adalah 76 dengan nilai minimum 44, sedangkan nilai maksimum peserta didik pada kelas eksperimen 2 sebesar 72 dengan nilai minimum sebesar 28. Tabel 1 dan Tabel 2 menunjukan terjadi peningkatan ratarata kedua kelas eksperimen. Hal ini menjelaskan bahwa dengan memberi kedua perlakuan yaitu kooperatif berbantuan AO (eksperimen 1) dan PBM (eksperimen 2) sehingga nilai rata-rata memiliki perbedaan yang cukup besar sebesar 15,88 sehingga mempengaruhi hasil belajar peserta didik.

Hasil tes akhir adalah salah satu bagian untuk menentukan uji hipotesis. Nilai $\chi_{\text {tabel dengan }}^{2}$ taraf signifikan $5 \%\left(\mathrm{~d}_{\mathrm{k}}=\mathrm{k}-1\right)$ adalah 11,07 . Nilai $\chi^{2}$ hitung peserta didik pada kelas eksperimen 1 dan kelas eksperimen 2 berturut-turut yaitu 19,52 dan 161,73. Hasil perhitungan yang diperoleh nilai $\chi_{\text {hitung }}^{2}>\chi_{\text {tabel }}^{2}$. Oleh karena itu, dapat dikatakan bahwa data tes akhir hasil belajar kedua kelas eksperimen tidak terdistribusi normal sehingga, uji statistik yang dapat digunakan untuk menguji hipotesis adalah uji statistik non-parametrik.

Uji hipotesis merupakan tahap akhir dari analisis data yang telah dilakukan dalam penelitian ini. Mengetahui perbedaan hasil belajar fisika dengan model kooperatif berbantuan advance organizer dan model pembelajaran berbasis masalah, maka data tes awal (pre-test) dan tes akhir (post-test) dijadikan sebagai data untuk uji hipotesis statistiknya. Asumsi ini didasarkan pada aturan, jika desain penelitian yang digunakan adalah pretest-posttest control group design maka perbedaan pencapaian antara kelompok eksperimen $1\left(\mathrm{O}_{2}-\mathrm{O}_{1}\right)$ dan eksperimen $2\left(\mathrm{O}_{4}-\mathrm{O}_{3}\right)$ merupakan efek dari treatment atau perlakuan yang diberikan [12]. Uji hipotesis yang digunakan adalah uji Mann-Whiteney (uji-U) karena kedua data (eksperimen 1 dan eksperimen 2) tidak terdistribusi normal. Hasil uji hipotesis dapat dilihat pada tabel 3.

Tabel 3. Menunjukan bahwa nilai $\mathrm{R}$ pada kelas eksperimen 1 adalah 718,5 serta kelas eksperimen 2 sebesar 1485. Peserta didik pada kelas eksperimen 1 dan eksperimen 2 masing-masing sebanyak 33 orang sehigga $\mathrm{R}$ yang akan digunakan untuk menghitung $\mathrm{U}$ adalah $\mathrm{R}$ yang paling kecil yaitu R kelas eksperimen 1. Setelah dilakukan perhitungan, didapatkan U sebesar 931,5. Syarat agar $\mathrm{H}_{0}$ dapat diterima apabila nilai berada pada $\mathrm{Z}_{\text {tabel }}<\mathrm{z}_{\text {hitung }}<\mathrm{z}_{\text {tabel }}$ yaitu $-1,96<\mathrm{z}_{\text {hitung }}<1,96$. Berdasarkan data pada Tabel 3, nilai $Z_{\text {hitung }}$ sebesar 4,98 tidak memenuhi syarat tersebut sehingga $\mathrm{H}_{0}$ ditolak. Hal ini menunjukan bahwa terdapat 
perbedaan hasil belajar fisika peserta didik kelas XI dengan model kooperatif berbantuan advance

organizer dan pembelajaran berbasis masalah.

Tabel 1. Data Kemampuan Awal Kelas Eksperimen 1 dan Kelas Eksperimen 2

\begin{tabular}{lcccc}
\hline Kelas & Jumlah data & $\begin{array}{c}\text { Nilai } \\
\text { Tertinggi }\end{array}$ & $\begin{array}{c}\text { Nilai } \\
\text { Terendah }\end{array}$ & Rata-rata \\
\hline Eksperimen 1 & 33 & 40 & 12 & 25,21 \\
Eksperimen 2 & 33 & 40 & 8 & 24,24 \\
\hline
\end{tabular}

Tabel 2. Hasil Tes Akhir Kelas Eksperimen 1 dan Kelas Eksperimen 2

\begin{tabular}{ccccc}
\hline Kelas & $\begin{array}{c}\text { Jumlah } \\
\text { data }\end{array}$ & $\begin{array}{c}\text { Nilai } \\
\text { Tertinggi }\end{array}$ & $\begin{array}{c}\text { Nilai } \\
\text { Terendah }\end{array}$ & Rata-rata \\
\hline Eksperimen 1 & 33 & 76 & 44 & 63,64 \\
Eksperimen 2 & 33 & 72 & 28 & 47,76 \\
\hline
\end{tabular}

Tabel 3. Hasil Uji Hipotesis Menggunakan Uji Mann-Whiteney

\begin{tabular}{cccccc}
\hline Kelompok & $\begin{array}{c}\text { Jumlah } \\
\text { Data (n) }\end{array}$ & $\mathbf{R}$ & $\mathbf{U}$ & Z hitung & $\mathbf{Z}_{\text {tabel }}$ \\
\hline Eksperimen 1 & 33 & 718,5 & 931,5 & 4,98 & 1,96 \\
Eksperimen 2 & 33 & 1485 & & & \\
\hline
\end{tabular}

Berdasarkan hasil analisis data tes kemampuan awal sebelum diberikan perlakuan diperoleh bahwa peserta didik kelas XI MIA 6 dan XI MIA 3 memiliki kemampuan awal yang sama (homogen). Hal ini sangat diperlukan untuk diketahui sebab kemampuan awal akan mempengaruhi hasil belajar. Nilai rata-rata yang didapat masih dapat dikatakan kurang yaitu ratarata kelas XI MIA 6 sebesar 25,21 sedangkan kelas XI MIA 3 sebesar 24,24. Oleh sebab itu, dapat dikatakan bahwa kemampuan awal peserta didik dikedua kelas rendah. Faktor yang menjadi alasan rendahnya kemampuan awal peserta didik karena kurangnya segi pemahaman terhadap konsep fisika secara menyeluruh. Peserta didik dilatih hanya pada bagian seputar persamaan-persamaan fisika saja, serta kurangnya penunjang yang diberikan sebagai penghubung pengetahuan peserta didik dalam memahami konsep fisika sehingga mempengaruhi hasil belajar.

Hasil belajar merupakan kemampuan yang harus dicapai setiap peserta didik setelah dilakukan suatu proses belajar mengajar. Berdasarkan hasil data yang dianalisis, nilai rata-rata tes akhir kelas XI MIA 6 (eksperimen 1) sebesar 63,64 dengan nilai tertinggi 76 dan terendah 44 sedangkan nilai rata-rata kelas XI MIA 3 sebesar 47,76 dengan nilai tertinggi 72 dan terendah 28. Nilai ini meningkat dari sebelum peserta didik diberi pembelajaran dengan model kooperatif berbantuan AO dan PBM. Akan tetapi, perbedaan peningkatan ini cukup besar. Hal ini dapat terlihat pada gambar 1. tes awal (pre-test) dengan tes akhir (post-test).
Gambar 1. memperlihatkan bahwa peningkatan nilai rata-rata setelah diberi perlakuan untuk kelas eksperimen 1 sebesar 38,43 sedangkan pada kelas eksperimen 2 peningkatan nilai rataratanya adalah 23,52 . Jadi, peningkatan nilai ratarata kelas eksperimen 1 lebih tinggi dibandingkan dengan kelas eksperimen 2. Perbedaan hasil belajar yang diperoleh dipengaruhi oleh perbedaan dari karakteristik model pembelajaran yang digunakan.

Pembelajaran kooperatif yang dilandaskan pada pembelajaran sosial Vygotsky yaitu konstruktivisme sosial yang menekankan keterlibatan peserta didik dengan orang lain dapat memberikan kesempatan dalam mengevaluasi dan memperbaiki pemahaman serta memberikan pemikiran yang terbuka untuk seluruh peserta didik, dalam mengungkapkan keinginan belajar [4].

Hal inilah yang menyebabkan hasil belajar yang diperoleh melalui pembelajaran kooperatif lebih baik dari pada PBM. Penelitian yang telah dilakukan di kelas XI MIA 6 yang proses pembelajaran menggunakan kooperatif berbantuan AO peserta didik cenderung lebih baik mengeluarkan pemikiran yang berkaitan dengan konsep fisika fluida statis, juga menekankan pada pembelajaran dengan timbal balik antar peserta didik, kemampuan sosial yang tinggi, maka peserta didik akan saling tukar pendapat dengan baik serta saling bertanggung jawab terhadap kelompok belajar. Penggunaan metode dan latihan berstruktur dan belajar kooperatif dapat meningkatkan kualitas proses dan hasil belajar [9]. Pembelajaran kooperatif tidak hanya mempelajari materi saja, namun peserta didik juga harus mempelajari 
keterampilan-keterampilan yang disebut keterampilan kooperatif. Sejalan dengan hal ini, melalui pembelajaran kooperatif maka peserta didik akan melakukan beragam tugas yang disesuaikan dengan kemampuan masing-masing sehingga dapat meningkatkan hasil belajar.

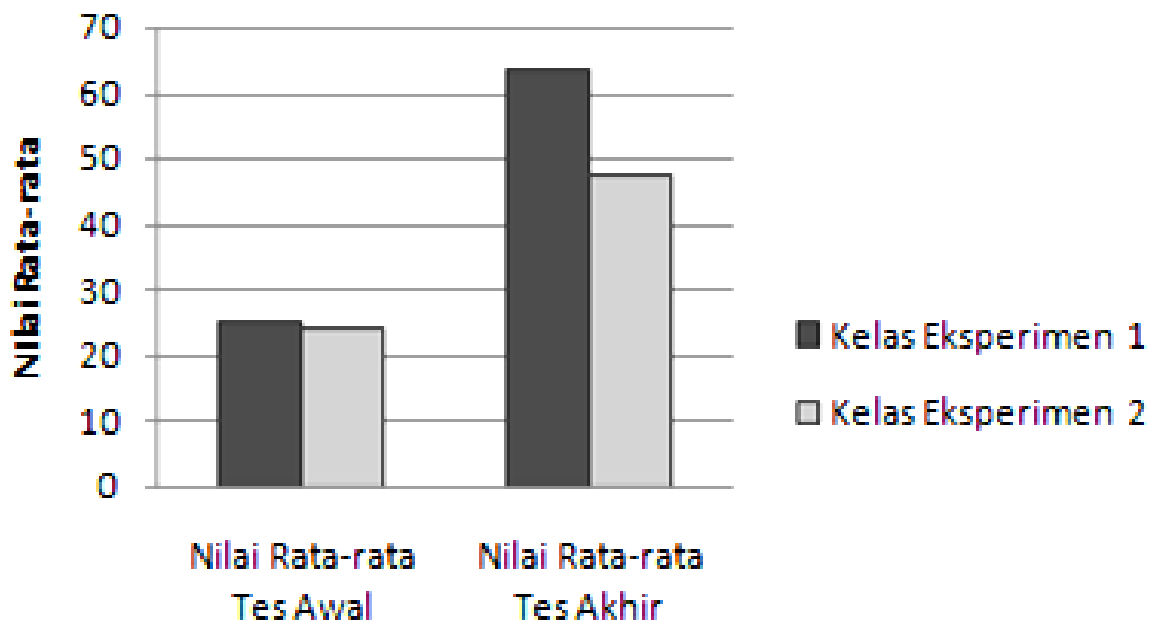

\section{Nilai Rata-rata Masing-masing Kelas}

\section{Gambar 1. Perbandingan Nilai Rata-rata Tes Awal dengan Tes akhir}

Model kooperatif memiliki tujuan, yaitu peserta didik dapat belajar secara berkelompok bersama teman sebaya; saling menghargai pendapat; dan memberikan kesempatan kepada orang lain untuk mengemukakan gagasannya dengan menyampaikan pendapat secara berkelompok [13]. Berdasarkan hal tersebut maka peserta didik akan memperoleh pembelajaran yang lebih baik bersama teman sebaya. Walaupun menemukan kendala kecil yaitu peserta didik yang menganggap dirinya kurang mampu akan menghambat jalannya diskusi, di samping itu pembelajaran ini memiliki beberapa kelemahan yaitu terhambat oleh peserta didik yang dianggap kurang memiliki kemampuan; ciri utama dari pembelajaran kooperatif adalah peserta didik saling membelajarkan, jika tanpa peer teaching yang efektif, dapat terjadi cara belajar yang tidak pernah dicapai oleh peserta didik; serta keberhasilan pembelajaran kooperatif dalam mengembangkan kesadaran berkelompok memerlukan waktu yang cukup lama [3].

Pembelajaran kooperatif berbantuan AO dan PBM merupakan model pembelajaran yang menekankan pada proses belajar agar peserta didik dapat mengembangkan kemampuan berpikir baik dari analisis maupun kerjasama kelompok. Pembelajaran kooperatif merupakan model pembelajaran yang baik untuk diterapkan dalam menunjang hasil belajar peserta didik. Keunggulan pembelajaran kooperatif yaitu meningkatkan kemampuan berpikir sendiri; mengembangkan kemampuan mengungkapkan ide atau gagasan; peduli pada orang lain; memberdayakan peserta didik untuk bertanggung jawab dalam belajar; serta mengembangkan prestasi akademik sekaligus kemampuan sosial [3]. Hal ini sejalan dengan proses pembelajaran yang telah dilakukan, yakni pembelajaran kooperatif lebih dominan terlihat adalah bagian positif. Sementara itu, untuk model PBM adalah bagian kelemahannya.

Bantuan advance organizer (AO) berupa peta konsep bertujuan memberikan fasilitas dalam belajar tentang materi faktual lebih banyak dari pada belajar dengan materi yang abstrak. AO dapat mendorong peserta didik agar perhatiannya terpusat sehingga pembelajaran lebih bermanfaat. AO dibangun dari seputar konsep-konsep utama pelajaran sehingga akan mudah diperkuat pengetahuannya serta memberikan landasan bagi materi pembelajaran baru untuk memperkuat pengetahuan kognitif [14]. Advance organizer (AO) akan memudahkan peserta didik dalam menyusun struktur kognitif agar lebih baik sehingga permasalahan yang menjadi bahan diskusi dalam kelompok kooperatif dapat berjalan secara maksimal dan menimbulkan pembelajaran yang lebih bermakna. AO dapat meningkatkan hasil belajar serta terdapat intraksi antara pemberian $\mathrm{AO}$ dengan hasil belajar peserta didik [5]. AO dapat meningkatkan hasil belajar dan aktivitas belajar peserta didik [15]. Bantuan AO berupa peta konsep dapat memaksimalkan belajar peserta didik dalam kelompok kooperatif. Dukungan teoritis menjelaskan bahwa proses belajar peserta didik melalui advance organizer berupa peta konsep berpengaruh positif terhadap hasil belajar fisika [7]. Sama halnya dengan penelitian oleh Hamdanillah 
et.al (2017) bahwa pembelajaran dengan menggunakan advance organizer dapat meningkatkan hasil belajar peserta didik.

Sementara itu, untuk peserta didik kelas XI MIA 3 yang telah diberi perlakuan dengan model PBM, diperoleh hasil belajar tidak maksimal dan kesulitan saat proses pembelajaran berlangsung. Kesulitan ini berkaitan dengan permasalahan yang harus mereka analisis terlebih dahulu pada LKPD karena membutuhkan tingkat analisis yang cukup tinggi terhadap suatu masalah yang diberikan. Perbedaan ini didasarkan karena tidak semua peserta didik memiliki tingkat analisis yang sama. Sulit memberikan penjelasan mengenai alasan kenapa suatu permasalahan dapat terjadi, sehingga disini pembimbingan yang dilakukan oleh peneliti sebagai guru lebih intensif. Selain itu, faktor lainnya yang mempengaruhi adalah kesulitan peserta didik dalam penyelesaian masalah jika permasalahan diaplikasikan ke dalam soal. Model pembelajaran berbasis masalah memiliki kekurangan yaitu : (1) peserta didik akan merasa enggan untuk mencoba manakala peserta didik tidak memiliki minat atau tidak mempunyai kepercayaan bahwa masalah yang diberikan akan dapat dipecahkan; (2) membutuhkan waktu yang cukup lama untuk melihat keberhasilan model pembelajaran ini; (3) tanpa pemahaman alasan mereka berusaha untuk memecahkan masalah yang sedang dipelajari maka mereka tidak akan belajar appa yang ingin dipelajar [3]. Pada prinsipnya model PBM, peserta didik sendirilah yang secara aktif mencari jawaban atas masalah-masalah yang diberikan guru [16]. Guru hanya sebagai mediator dan fasilitator untuk membantu peserta didik dalam mengkonstruksi pengetahuan mereka secara efektif. Pembelajaran ini mengharuskan peserta didik memiliki tingkat analisis yang tinggi, sedangkan tidak semuanya mampu dalam tahap itu. Hal ini dirasakan oleh peneliti saat dalam fase pembelajaran yaitu membantu dalam investigasi masalah. Saat peneliti mengajukan beberapa pertanyaan berkaitan dengan permasalahan yang didiskusikan, hanya beberapa peserta didik yang bisa, dan banyak yang merasa kesulitan.

Rata-rata hasil belajar yang diperoleh melalui model PBM seperti pada Gambar 1 . memperlihatkan bahwa setelah diberikan perlakuan terdapat peningkatan walaupun dalam kategori kecil. Hal ini membuktikan bahwa untuk melihat efektivitass sebuah model pembelajaran memerlukan waktu yang cukup lama. Pembelajaran berbasis masalah dapat meningkatkan hasil belajar peserta didik [17]. Pembelajaran berbasis masalah dengan metode diskusi dapat meningkatkan hasil belajar fisika [18]. Model PBM memberikan pengaruh lebih baik terhadap hasil belajar fisika [19]. Kelebihan dari model PBM yaitu : pemecahan masalah merupakan teknik yang bagus untuk lebih mudah dalam memahami pembelajaran; pemecahan masalah dapat menantang kemampuan peserta didik dalam memberikan kepuasan untuk menemukan pengetahuan baru; meningkatkan aktivitas pembelajaran peserta didik; membantu peserta didik dalam mentransfer pengetahuan untuk memahami masalah dalam kehidupan nyata; mendorong peserta didik untuk melakukan evaluasi sendiri baik terhadap hasil maupun proses belajarnya [3]. Penelitian sebelumnya memperlihatkan bahwa PBM sebenarnya dapat meningkatkan hasil belajar, akan tetapi jika dibandingkan dengan kooperatif berbantuan AO ternyata hasil belajar yang diperoleh lebih besar dari pada melalui PBM. Kata lainnya yang mendasari kurangnya hasil belajar peserta didik dengan PBM karena yang muncul saat proses pembelajaran lebih banyak kepada kekurangan PBM itu sendiri. Untuk melihat hasil yang lebih baik dan efektivitas sebuah model baik itu kooperatif berbantuan AO maupun PMB maka diperlukan waktu yang cukup lama.

Faktor-faktor diatas merupakan alasan kenapa hasil belajar peserta didik berbeda. Walaupun dengan peningkatan nilai rata-rata yang tidak besar dari sebelum diberikan perlakuan, namun kedua model pembelajaran yaitu kooperatf berbantuan advance organizer (AO) dan PBM memiliki karakteristik tersendiri baik dari keunggulan maupun kelemahan dari masingmasing model sehingga mempengaruhi cara belajar terhadap peserta didik, dan hal ini dapat ditunjukan dengan hasil belajar yang diperoleh peserta didik. Keantusiasan dan keaktifan peserta didik dalam berdiskusi maupun belajar mempengeruhi juga pada ranah efektif maupun psikomotor. Tiga ranah ini saling berhubungan sehingga mempengaruhi hasil belajar yang diperoleh peserta didik.

\section{KESIMPULAN}

Berdasarkan hasil dan pembahasan dapat disimpulkan bahwa terdapat perbedaan hasil belajar fisika peserta didik kelas XI dengan model kooperatif berbantuan advance organizer dan pembelajaran berbasis masalah. Adapun saran yang dapat diberikan yaitu model kooperatif berbantuan advance organizer dapat digunakan sebagai salah satu cara dalam meningkatkan hasil belajar fisika peserta didik. Untuk melihat hasil yang lebih baik dengan menggunakan model PBM maupun kooperatif berbantuan $\mathrm{AO}$, sebaiknya penelitian tidak hanya dilakukan pada satu sub materi pembelajaran fisika. Perhatikan alokasi waktu, maupun bahan ajar yang digunakan.

\section{DAFTAR PUSTAKA}

[1] Gagne, R.M. 1974. Essentials of Learning for Instruction. (diterjemahkan oleh : Abdillah Hanafi) 1998. Surabaya: Usaha Nasional.

[2] Sugiyanto. 2010. Model-Model Pembelajaran Inovatif. Surakarta: Yuma Pustaka. 
[3] Sanjaya, W. 2008. Strategi Pembelajaran Berorientasi Standar Proses Pendidikan. Jakarta : Kencana Prenada Media Group.

[4] Nur, M dan Wikandari, P.R. 2000. Pengajaran Berpusat Kepada Siswa dan Pendekatan Kontruktivis dalam Pengajaran. Surabaya: Pusat Sains dan Metamatika Universitas Negeri Surabaya.

[5] Harjono, A. 2010. Perbedaan Strategi Pembelajaran dan Pemberian Advance Organizer Pengaruhnya Terhadap Hasil Belajar Fisika Kelas X. Jurnal Pijar MIPA Universitas Mataram, hal(13-17).

[6] Ausubel, D.P, Novak, J.D, dan Helen, H. 1978. Educational Psychology A Cognitive View Second Edition.New York Chicago San Fransisco Dallas Monteral Toronto London Sydney.

[7] Nopiani, R, Harjono, A, dan Hikmawati. 2017. Pengaruh Model Pembelajaran Advance Organizer Berbantuan Peta Konsep Terhadap Hasil belajar Fisika SMA Negeri 1 Lingsar. Jurnal pendidikan Fisika dan Teknologi, hal (137-145).

[8] Aziz, A. 2009. Model Advance Organizer dan Penerapannya dalam Pembelajaran. JurnalTa'allum. Vol. 19 (1): 34-44.

[9] Sutrio, Harjono, A, dan Rahayu, S. 2016. Metode Latihan Berstruktur dan Belajar Kooperatif untuk Meningkatkan Penguasaan Konsep Listrik Magnet Calon Guru Fisika. Jurnal Pendidikan Fisika dan Teknologi, Volume II No.4 Oktober 2016, hal (170-175).

[10] Warsono dan Hariyanto. 2017. Pembelajaran Aktif Teori dan Asesmen. Bandung: PT.Remaja Rosdakarya.

[11]Suprijono, A. 2011. Cooperative Learning Teori dan Aplikasi PAIKEM. Yogjakarta: Pustaka Belajar.

[12] Arikunto, S. $2014 . \quad$ Prosedur Penelitian.Jakarta: Rineka Cipta.

[13] Isjoni. 2009. Cooperative Leraning. Bandung: Alfabeta.
[14] Joyce, B, Weil, M dan Calhoun, E. 2015. Model Of Teaching Ninth Edition, (diterjemahkan oleh : Rianyati Kusmini Pancasari), Yogjakarta:Pustaka Pelajar.

[15] Sinulingga, K dan Munte, D. 2012. Pengaruh Model Pembelajaran Advance Organizer Berbasis Mind Map Terhadap Hasil Belajar Fisika Siswa Pada Materi Pokok Besaran dan Satuan di Kelas X SMA. Jurnal Pendidikan Fisika, hal (1- 6).

[16]Lestari, S. 2011. Pengaruh Model Pembelajaran Berbasis Masalah (Problem Based Learning) dan Motivasi Belajar Terhadap Prestasi Belajar Fisika Bagi Siswa Kelas VII SMP.Jurnal Pendidikan Ganesha, hal (1-21).

[17] Wulandari, B dan Surjono, H.D. 2012. Pengaruh Problem-Based Learning Terhadap Hasil Belajar Ditinjau Dari Motivasi Belajar PLC Di SMK.Jurnal Pendidikan Vokasi, hal (178-191).

[18] Azmi, M.K, dan Rahayu. S, dan Hikmawati. 2016. Pengaruh Model Problem Based Learning dengan Metode Eksperimen dan Diskusi Terhadap Hasil Belajar Fisika Ditinjau dari Sikap Ilmiah Siswa Kelas X MIPA SMAN 1 Mataram. Jurnal Pendidikan Fisika dan Teknologi.hal (86-94).

[19] Hardiyanto, Susilawati, dan Harjono, A. 2015. Pengaruh Model Pembelajaran Berbasis masalah dan Ekspositori dengan Keterampilan Proses Sains Terhadap Hasil Belajar Fisika Siswa Kelas VIII MTSN 1 Mataram Tahun Ajaran 2014/2015. Jurnal Pendidikan Fisika dan Teknologi, hal (249-256).

[20] Hamdanillah, N, Harjono, A, dan Susilawati. 2017. Pengaruh Model Pembelajaran Advance Organizer Menggunakan Video Pembelajaran Terhadap Hasil Belajar Fisika Peserta Didik Kelas XI. Jurnal Pendidikan Fisika dan Teknologi, hal (119-127). 